\title{
IMPLEMENTATION OF VALUE ENGINEERING IN MARKET DEVELOPMENT ON YOS SUDARSO STREET IN ANGGANA DISTRICT, KUTAI KARTANEGARA REGENCY OF EAST KALIMANTAN, INDONESIA
}

\author{
Purwanto Ary*, Researcher \\ Kustamar, Wedyantadji Bambang, Lecturers \\ National Institute of Technology, Malang, East Java, Indonesia \\ *E-mail: ar141to@yahoo.co.id \\ ORCID 0000-0003-2743-5592
}

\begin{abstract}
The objectives of this present research are to: 1) know the elements potentially saved or made it efficient by using value engineering method; 2) know how far this efficiency can be implemented in the market development project. This research uses observation method. Moreover, the secondary data of this present research are in form of supporing data which are made as input and references in doing VE Analysis. The result of this research, after doing calculation of footing structure redesign, shows that the dimension result is greater than the initial planning, but the footing of Pile Cap (P1 \& P2) is able to work by itself to have a load on it without combining with pile. Roof structure does not have significant structure redesign; it is only on the working of WF steel column, WF truss leg, and WF Dimension Hemishphere can be minimized so that the cost or the budget for the project can be saved. The work of footing structure is in line with the initial calculation and after doing value engineering, it obtains the initial design budget is of IDR 1.424.428.066,51 and the cost of value engineering analysis result is of IDR $351.280 .587,88$. It means that by implementing value engineering, it can save IDR $1.073 .147 .478,63$ with saving percentage is of $75,339 \%$. The work of roof structure is in accordance with the initial calculation result and after doing value engineering, it is obtained that the initia design cost is of IDR $885.493 .900,20$ and the cost of value engineering analysis result is of IDR 751.756.078,50. It shows that by implementing the value engineering, it can save IDR $133.737 .821,70$ with saving percentage is of $15,133 \%$.
\end{abstract}

\section{KEY WORDS}

Value engineering, market, streets, reconstruction, budget.

Value Engineering (VE) is an organized creative approach which its function is to optimize the cost and/or the performance of a facility or a system (Dell'Isola, 1997). The approach used is directed to function analysis. If it does not have beneficial characteristics to the needs, the cost is spent without decreasing the quality and it still protects the environment as wel as prioritizes safety (Paraoulaki, 2000; Azis, 2016).

VE is used to search alternatives or ideas which aim to gain better/lower cost from the planned price previously with functional limitation and work quality (Ibusuki \& Kaminski, 2007). Besides, VE can also be used to improve performance, quality, and life cycle cost. In VE planning, it usually involves the project owner, planner, the experts, and VE consultants (Kelly \& Male, 2003).

It is expected that by implementing this value engineering, it will save cost of $25 \%$. It extremely provides saving benefits for the project owner and also for the project implementers. Based on the data obtained from PT. Setia Jaya Utama, the research conducts a review in form of a research regarding to value engineering in the project of Market Development in Yos Sudarso Street in Anggana District, Kutai Kartanegara Regency, East Kalimantan, so that in this research, the researcher provides a title with "Implementation of Value Engineering in Market Development in Yos Sudarso Street in Anggana District, Kutai Kartanegara Regency, East Kalimantan". However, for this present research, the research only focuses on footing work and roof truss. With the presence of reinforced 
concrete footing with the combination of pile and pile cap as well as WF steel truss $200 \times 100 \times 5.5 \times 8$, it is expected that the project can save budget much.

Research Questions:

- What are the costs components potentially saved or made it efficient by using value engineering method in Market Development project in Yos Sudarso in Anggana District, Kutai Kartanegara Regency, East Kalimantan?

- How far this efficiency can be implemented in the project of Market Development in Anggana District, Kutai Kartanegara Regency, East Kalimantan?

Research Objectives:

- To know the cost components potentially saved or made it efficient by using value engineering method in Market Development project in Yos Sudarso in Anggana District, Kutai Kartanegara Regency, East Kalimantan;

- To know How far this efficiency can be implemented in the project of Market Development in Anggana District, Kutai Kartanegara Regency, East Kalimantan.

\section{METHODS OF RESEARCH}

In this research, a strategy recommended by Brinkkemper (1996) is used with the aim to be able to answer the questions in the research. There are three factors affecting the type of research strategy, which are (Afandi, 2010):

- The type of questions asked;

- The width of control had by the researcher on the event that will be studied;

- The focus on the contemporary event as the reverse of historical event.

The research method used here explains about what method that will be used in this research. The strategy in determing the research method can be seen in the table below:

Table 1 - Strategy of Choosing Research Method

\begin{tabular}{|c|c|c|c|}
\hline Strategies & Questions forms of the researcher & $\begin{array}{c}\text { Control from the researcher } \\
\text { with an action from actua } \\
\text { research }\end{array}$ & $\begin{array}{c}\text { Level of focus from previous } \\
\text { research similarity }\end{array}$ \\
\hline Analysis & Who, what, where, how many & No & No \\
\hline Historical & How, why & No & No \\
\hline Case Study & How, why & No & Yes \\
\hline
\end{tabular}

Data Collection Method. Data collection method is the techniques or ways used by the researcher to collect data. In collecting data, it also needs data collection instrument which is the selected helping tool and used by the researcher in the activity of collecting data in order that the activity becomes systematic. The data used in the research consist of two types namely: Primary Data is the data taken directly from the research object. The primary data is the main data used for value engineering analysis. Primary data in this research can be in form of project technical data, like project figure, Budget Cost Plan (RAB), Working Plans and Conditions (RKS). Secondary Data is the data obtained indirectly from the research object. In this research, secondary data can be in form of supporting data which are taken as input and reference in doing VE analysis (Younker, 2003). Secondary data comprise of list of unit price or working analysis, material data, material, and building tools used, workers data, rules than can be made as a reference in doing VE analysis (Miles, 2015).

Observation is a direct observation to the research object to see the project done closer. Observation is done in the phase of information collection. Primary data colletion method is done by direct survey to consultans and implementers who handle the project and doing observation directly to the field. While, for secondary data collection method, direct survey to institutions or companies considered involving is done. The companies can cover building material companies, contractor, and other companies that can be taken as a reference. 
The decision taken is based on the condition of the environment or the existing condition, like certain condition, risky condition, uncertain condition, and conflicting condition. In decision making, there are some models like:

- Quantitative model (in this case, mathematical model) is a series of right assumption stated in the series of certain mathematical relation. It can be in form of equation or other analysis, or is an instruction for computer, in form of programs for computer;

- Qualitative model is based on the assumptions in which its accuracy is less if compared to quantitative model and its characteristics are portrayed through combination from the assumption deductions and with more subjective consideration related to process or problem in which its solution is made in model. Gullet and Hicks provide some model classifications of decision making which is frequently used to solve such problems (in which its result is less known accurately);

- Probability model; in general, its decision models are probability concepts and the concepts expected provide certain results.

VE analysis.

Data Analysis. The analysis used to answer both research questions in this research is

\section{RESULTS OF STUDY}

Project Description. General Data of the project of Market Development in Anggana District, Kutai Kartanegara Regency, East Kalimantan is as follows:

- Project Name: Market Development in Yos Sudarso; Street, Anggana District, Kutai Kartanegara Regency, East Kalimantan;

- Project Site: Anggana District, Kutai Kartanegara; Regency, East Kalimantan;

- Project Owner: Office of Human Settlements and Spatial; Planning of Kutai Kartanegara Regency;

- Management Consultant: PT. Bennatin Surya Cipta;

- Implementer Consultant: Gemilang Surya Inti;

- Implementer Contractor: PT. Setia Jaya Utama;

- Building Width: $\pm 1.190 \mathrm{~m}^{2}$;

- Cost: IDR 25.331.101.000, -.

Information Phase. This phase is the process of search and information collection aiming to obtain clear comprehension from study items which will be reviewed or studied by collecting supporting data as many as possible. Information result or the data can be seen in the table below.

Table 2 - Data Information

\begin{tabular}{|c|c|c|}
\hline \multicolumn{3}{|c|}{ Project Data: MARKET DEVELOPMENT ON YOS SUDARSO STREET } \\
\hline \multicolumn{3}{|c|}{ Item: Work of Concrete and Steel Structure (Beam, Column, and Steel Roof) } \\
\hline No & Information Source & Obtained Data \\
\hline \multirow{3}{*}{1} & \multirow{3}{*}{ PT. SETIA JAYA UTAMA } & > Plan Description \\
\cline { 3 - 3 } & & > Detail Figure \\
\cline { 3 - 3 } & & > Cost Budget Plan (RAB) \\
\cline { 2 - 3 } & & Psbuilt Drawing Figure \\
\hline
\end{tabular}

Source: PT. Setia Jaya Utama.

Table 3 - Data of Technical Project

\begin{tabular}{|c|c|c|}
\hline \multicolumn{3}{|c|}{ Project Data: DEVELOPMENT OF PERSADA HOSPITAL BUILDING } \\
\hline \multicolumn{3}{|c|}{ Item: Work of Concrete Structure (Beam, Flat, and Column) } \\
\hline No & Description & Obtained Data \\
\hline \multirow{3}{*}{1} & Criteria of Concrete and Steel Design Desain Beton & $>$ Concrete quality used K-225 \\
\cline { 2 - 3 } & Design & $>$ Steel quality used fu 320 Mpa \\
\cline { 2 - 3 } & & $>$ Steel quality used fy 240 Mpa \\
\hline
\end{tabular}

Source: PT. Setia Jaya Utama. 
Type of portal constructionReinforced concrete:

- Quality of concrete: K-225;

- Quality of plain steel bars: U. 24;

- Quality of threaded steel bars: U. 32.

Type of roof: WF Steel:

- Strong melting (fy): $240 \mathrm{Mpa}$;

- Strong breaking (fu): $320 \mathrm{Mpa}$.

The regulations used in this research are as follows:

- Regulation of Indonesia Loading for Building, 1983;

- Operational Standard of Concrete Calculation for Building SNI- 2847-2002;

- Ir. Gideon H Kusuma M. Eng, Basics of Reinforced Concrete Planning, Erlangga Jakarta.

Initial Condition of Project. The real condition or the condition in the field for base structure or footing in the project of Market Development in Anggana District, Kutai Kartanegara Regency, East Kalimantan uses combination between pile cap and pile. For more detail footing structure, it can be seen in the table below.

Table 4 - Footing Condition

\begin{tabular}{|c|c|c|c|c|}
\hline No & Description & Material & Dimension & Quality \\
\hline 1 & P1 Pile Cap & Reinforced Concrete & $65 \times 65 \times 30$ & K-225 \\
\hline 2 & P2 Pile Cap & Reinforced Concrete & $155 \times 80 \times 30$ & K-225 \\
\hline 3 & Pile & Reinforced Concrete & $25 \times 25$ & - \\
\hline
\end{tabular}

Source: PT. Setia Jaya Utama.

The Work of Column Structure. The real condition or the condition in the field column structure in the project of Market Development in Anggana District, Kutai Kartanegara Regency, East Kalimantan uses reinforced concrete material in which it can be seen in the table below for more details.

Table 5 - Initial Condition of Column Structure

\begin{tabular}{|c|c|c|c|c|}
\hline No & Description & Material & Dimension & Quality \\
\hline 1 & KP Column & Reinforced Concrete & $15 \times 15$ & K-225 \\
\hline 2 & K1 Coumn & Reinforced Concrete & $20 \times 20$ & K-225 \\
\hline 3 & K2 Column & Reinforced Concrete & $25 \times 25$ & K-225 \\
\hline
\end{tabular}

Source: PT. Setia Jaya Utama.

The real condition or the condition in the field for roof structure in the project of Market Development in Anggana District, Kutai Kartanegara Regency, East Kalimantan employs WF Steel material in which the more detail can be seen in the table below.

Table 6 - Initial Condition of Roof Structure

\begin{tabular}{|c|c|c|c|}
\hline No & Description & Material & Dimension \\
\hline 1 & Main Structure & WF Steel & $200 \times 100 \times 5.5 \times 8$ \\
\hline 2 & Gording & C Steel & $100.50 .20 .2,3$ \\
\hline 3 & Roof Cover & Spandek & \\
\hline
\end{tabular}

Source: PT. Setia Jaya Utama.

Identification of High Cost. From the analysis of the project cost budget plan of Market Development in Anggana District, Kutai Kartanegara Regency, East Kalimantan, the complete cost budget recapitulation can be seen from the table 7 .

It can be seen that the biggest weight work is in the market stall for concrete work $(16,489 \%)$, roof construction work $(9,732 \%)$, and footing $(6,186 \%)$. For market ward work, the highest weight percentage is in concrete work item (6,927\%). 
Table 7 - Cost Budget Recapitulation

\begin{tabular}{|c|c|c|c|}
\hline $\mathrm{NO}$ & ITEM PEKERJAAN & BIAYA & Weight (\%) \\
\hline A. & \multicolumn{3}{|c|}{ MARKET WARD } \\
\hline A1 & PREPARATORY WORK & IDR $11.287 .360,00$ & 0,049 \\
\hline $\mathrm{A} 2$ & LAND WORK & IDR 133.625.951,80 & 0,580 \\
\hline A3 & FOOTING & IDR 730.899.024,85 & 3,174 \\
\hline A4 & CONCRETE WORK & IDR $1.595 .109 .923,61$ & 6,927 \\
\hline A5 & ROOF CONSTRUCTION WORK & IDR $768.272 .937,87$ & 3,336 \\
\hline A6 & INSTALLATION WORK & IDR $1.221 .680 .506,40$ & 5,305 \\
\hline A7 & PAINTING WORK & IDR $112.767 .149,01$ & 0,490 \\
\hline A8 & FLOORING WORK & IDR $485.351 .086,15$ & 2,108 \\
\hline A9 & DOOR \& WINDOW WORK & IDR 9.153.189,43 & 0,040 \\
\hline A10 & SANITY WORK & IDR $6.551 .760,00$ & 0,028 \\
\hline A11 & DIRTY WATER CHANNEL WORK & IDR $39.777 .306,80$ & 0,173 \\
\hline A12 & CKEAN WATER CHANNEL WORK & IDR $56.080 .738,00$ & 0,244 \\
\hline A13 & ELECTRICITY WORK & IDR $132.708 .806,00$ & 0,576 \\
\hline A14 & CIRCUMFERENCE CHANNEL WORK & IDR $1.030 .272 .096,21$ & 4,474 \\
\hline A15 & LEFT \& RIGHT FENCING WORK & IDR $511.609 .741,56$ & 2,222 \\
\hline A16 & REAR FANCE WORK & IDR $224.045 .795,13$ & 0,973 \\
\hline A17 & CONCRETE ROAD WORK & IDR $2.666 .991 .665,48$ & 11,581 \\
\hline B. & \multicolumn{3}{|c|}{ MARKET STALL } \\
\hline $\mathrm{B} 1$ & FOOTING & IDR 1.424.428.066,51 & 6,186 \\
\hline B2 & CONCRETE WORK & IDR 3.796.245.065,18 & 16,485 \\
\hline B3 & ROOF CONSTRUCTION WORK & IDR 2.241.117.376,37 & 9,732 \\
\hline B4 & INSTALLATION WORK & IDR 2.059.554.583,83 & 8,944 \\
\hline B5 & FLOORING WORK & IDR $459.881 .050,40$ & 1,997 \\
\hline B6 & DOOR \& WINDOW WORK & IDR 476.657.791,05 & 2,070 \\
\hline B7 & CEILING WORK & IDR 223.082.123,27 & 0,969 \\
\hline B8 & PAINTING WORK & IDR 198.859.474,70 & 0,864 \\
\hline B9 & OTHER WORKS & IDR 210.103.193,50 & 0,912 \\
\hline $\mathrm{B} 10$ & SANITY WORK & IDR $7.419 .840,00$ & 0,032 \\
\hline $\mathrm{B} 11$ & DIRTY WATER CHANNEL WORK & IDR 23.422.209,60 & 0,102 \\
\hline $\mathrm{B} 12$ & CKEAN WATER CHANNEL WORK & IDR 26.499.346,00 & 0,115 \\
\hline B13 & ELECTRICITY WORK & IDR $143.146 .260,00$ & 0,622 \\
\hline B14 & CIRCUMFERENCE CHANNEL WORK & IDR 382.019.067,04 & 1,659 \\
\hline B15 & CONCRETE ROAD WORK & IDR 967.437.309,21 & 4,201 \\
\hline B16 & WASTEWATER TREATMENT PLAN WORK & IDR 362.933.821,45 & 1,576 \\
\hline $\mathrm{B} 17$ & SCREEN GRIT \& BALANCE TANK WORK & IDR $70.173 .282,00$ & 0,305 \\
\hline B18 & CHLORINE \& MONITORING CONTACT & IDR $8.571 .122,45$ & 0,037 \\
\hline $\mathrm{B} 19$ & RAIN WATER TANK 3×5x2.25 m3 & IDR 210.537.982,38 & 0,914 \\
\hline & GRAND TOTAL OF STANDARD WORKS & IDR 23.028.274.003,22 & 100,000 \\
\hline & BKF & IDR 23.028.274.003,22 & \\
\hline & VAT $10 \%$ & IDR 2.302.827.400,32 & \\
\hline & Grand Total of Works & IDR 25.331.101.403,54 & \\
\hline & Rounded to & IDR 25.331.101.000,00 & \\
\hline
\end{tabular}

Source: PT. Setia Jaya Utama.

To determine the work type which has high cost or expence, calculation as shown in the table below is used, but for work item selction, it only uses Market Stall work because there is a work for Market Stall having a high weight relatively.

From table 8 above, it can be known that the comparison of working item cost tota towards the entire working items like concrete work, footing, and roof construction work. Then, from the table above, it also can be known that the concrete work has the highest weight of $50,88 \%$, then the second highest weight is on the roof construction work of $30,03 \%$, and the third highest weight or the last is on the footing of $19,09 \%$.

After obtaining three working items above, the working item weight on concrete work is not that effective to have value engineering because there are several sub-works with a relatively small work in the concrete work. Therefore, for value engineering, it is more optimized on footing and roofing and value engineering done by conducting structure redesign by not changing both the form and the function of the structure. Thus, alternative of footing and roofing structure will be done as expected which is strong, efficient, and safe. 
Table 8 - Break Down Analysis

\begin{tabular}{|c|c|c|c|c|c|}
\hline NO. & WORKING ITEMS & TOTAL PRICE & \begin{tabular}{|c} 
TOTAL WEIGHT \\
OF PRICE \\
$(\%)$
\end{tabular} & CUMMULATIVE & $\begin{array}{c}\text { CUMMULATIVE } \\
\text { WEIGHT } \\
(\%) \\
\end{array}$ \\
\hline $\mathrm{B} 1$ & FOOTING & & & & \\
\hline 1, & Procurement of pile $25 \times 25$ & IDR $801.870 .960,00$ & \multirow{5}{*}{19,09} & \multirow{5}{*}{$\begin{array}{c}\text { IDR } \\
1.424 .428 .066,51\end{array}$} & \multirow{5}{*}{19,09} \\
\hline 2, & Piling of pie $25 \times 25$ & IDR 351.738.432,00 & & & \\
\hline 3 & Rebated Concrete $\mathrm{t}=5 \mathrm{~cm}$ & IDR $9.842 .957,14$ & & & \\
\hline 4, & P1 Pile Cap (65×65×30 cm, K-225) & IDR $71.250 .216,29$ & & & \\
\hline \multirow[t]{2}{*}{5 , } & P2 Pile Cap $(155 \times 65 \times 30 \mathrm{~cm}, \mathrm{~K}-225)$ & IDR 189.725.501,08 & & & \\
\hline & Total & IDR1.424.428.066,51 & \multicolumn{3}{|c|}{--} \\
\hline B2 & \multicolumn{5}{|c|}{ CONCRETE WORK } \\
\hline 1, & Rebated Concrete $\mathrm{t}=5 \mathrm{~cm}, \mathrm{~K}-100$ & IDR 147.287.644,87 & \multirow{13}{*}{50,88} & \multirow{13}{*}{$\begin{array}{c}\text { IDR } \\
5.220 .673 .131,69\end{array}$} & \multirow{13}{*}{69,97} \\
\hline 2, & $\begin{array}{c}\text { Basement } \mathrm{t}=12 \mathrm{~cm} \text { wiremesh reinforce } \mathrm{M} \text { - } \\
8, \mathrm{~K}-225\end{array}$ & IDR 986.987.681,51 & & & \\
\hline 3 & Sloof $20 / 30, \mathrm{~K}-225$ & IDR $633.369 .458,09$ & & & \\
\hline 4, & KP Column (15/15) (K-225) & IDR $87.465 .016,77$ & & & \\
\hline 5, & K1 Column (20/20) (K-225) & IDR 335.698.133,46 & & & \\
\hline 6 & K2 Column (25/25) (K-225) & IDR 213.522.384,60 & & & \\
\hline 7 & B1 Beam (15/15) (K-225) & IDR 128.801.977,25 & & & \\
\hline 8, & B2 Beam (20/30) (K-225) & IDR $\quad 6.782 .344,43$ & & & \\
\hline 9 & B3 Bam (20/30) (K-225) & IDR 417.994.334,04 & & & \\
\hline 10 & B4 Beam (15/25) (K-225) & IDR 102.158.547,20 & & & \\
\hline 11, & K2 Column (25/25) (K-225) & IDR $18.477 .898,67$ & & & \\
\hline 12, & Roof base flat $\mathrm{t}=12 \mathrm{~cm}(\mathrm{~K}-225)(\mathrm{K}-225)$ & IDR 554.983.429,89 & & & \\
\hline \multirow[t]{2}{*}{13,} & Water proofing of roof base & IDR $162.716 .214,40$ & & & \\
\hline & Total & IDR3.796.245.065,18 & \\
\hline B3 & \multicolumn{5}{|c|}{ ROOF CONSTRUCTION WORK } \\
\hline 1, & WF Column $200 \times 100 \times 5.5 \times 8$ & IDR $65.897 .220,48$ & \multirow{18}{*}{30,03} & \multirow{18}{*}{$\begin{array}{c}\text { IDR } \\
7.461 .790 .508,07\end{array}$} & \multirow{19}{*}{100,00} \\
\hline 2 & WF Truss Leg $200 \times 100 \times 5.5 \times 8$ & IDR $770.173 .764,36$ & & & \\
\hline 3 & WF Hemisphere $200 \times 100 \times 5.5 \times 8$ & IDR $49.422 .915,36$ & & & \\
\hline 4, & Gording C100.50.20.2,3 & IDR 438.539.511,48 & & & \\
\hline 5 & Treckstank iron with diameter $10 \mathrm{~mm}$ & IDR $33.089 .968,79$ & & & \\
\hline 6 & Thick Stiffener Rib t=8 mm & IDR $21.836 .954,16$ & & & \\
\hline 7, & Plendes flat, flat for bolt coupling $\mathrm{t}=10 \mathrm{~mm}$ & IDR $49.284 .792,38$ & & & \\
\hline 8 & $\begin{array}{l}\text { Steel Square with width } 70.70 .7 \text { as gording } \\
\text { holder }\end{array}$ & IDR 28.513.220,40 & & & \\
\hline 9, & Tensile member with diameter $19 \mathrm{~mm}$ & IDR $68.793 .378,14$ & & & \\
\hline 10 & Strong needle with diamter $19 \mathrm{~mm}$ & IDR $2.145 .290,00$ & & & \\
\hline 11, & Colourbond spandek roof cover & IDR 310.953.362,54 & & & \\
\hline 12, & Colourbond spandek ridge & IDR $18.467 .621,90$ & & & \\
\hline 13 & $\begin{array}{l}\text { Alluminium foil } 1 \text { side }+ \text { glass wool with } \\
\text { thickness } 10 \mathrm{~cm}+\text { harmonica wire }\end{array}$ & IDR 203.942.661,19 & & & \\
\hline 14 & Flashing alluminium & IDR $29.090 .668,80$ & & & \\
\hline 15 & Listplank spandek & IDR $69.692 .594,40$ & & & \\
\hline 16 & HTB Bolt with diameter $12 \mathrm{~mm}$ & IDR $11.657 .100,00$ & & & \\
\hline 17 & $\begin{array}{c}\text { Anchor bolt with diameter } 16 \mathrm{~mm} \text {, Width } \\
=40 \mathrm{~cm}\end{array}$ & IDR 22.062.320,00 & & & \\
\hline \multirow[t]{2}{*}{18,} & Zinc Chromate Paint & IDR $47.554 .032,00$ & & & \\
\hline & Total & IDR2.241.117.376,37 & & \\
\hline
\end{tabular}

Function Analysis. For function analysis for footing, total or combined footing structure calculation will be done from pile cap footing and pile. It is because in the structure planning, it only conducts interrelated planning between pile cap footing and pile.

Table 9 - Unit Price Analysis of Applying Profile Iron (per $1 \mathrm{~kg}$ )

\begin{tabular}{|c|c|c|c|c|}
\hline Coef & Unit & Material & Unit Price & Total \\
\hline 1,15 & $\mathrm{Kg}$ & WF Steel & IDR $36.000,00$ & IDR $41.400,00$ \\
\hline \multicolumn{4}{|c|}{ Total (1) } & IDR $41.400,00$ \\
\hline 0,060 & Person & Workers & IDR $88.000,00$ & IDR $5.280,00$ \\
\hline 0,060 & Person & Welder & IDR 121.000,00 & IDR $7.260,00$ \\
\hline 0,006 & Person & Head of Handyman & IDR 132.000,00 & IDR 792,00 \\
\hline 0,003 & Person & Foreman & IDR 154.000,00 & IDR 462,00 \\
\hline \multicolumn{4}{|c|}{ Total (2) } & IDR $13.794,00$ \\
\hline \multicolumn{4}{|c|}{ Total (1) + (2) } & IDR 55.194,00 \\
\hline
\end{tabular}


For planning alternative, planning minimizing piling will be done because the procurement of pile has a relatively high cost in piling. With the structure of one floor and the area of this building which does not have the possibility of earthquake, it is expected that this value engineering calculation obtains footing volume decreasing which is quite big so that it can reduce the cost for footing.

\section{WF Truss Leg $200 \times 100 \times 5.5 \times 8$ \\ Volume $=$ Length $\times$ WF Steel $200 \times 100 \times 5.5 \times 8=13.953,94 \mathrm{Kg}$}

The analysis of the unit price is then timed with the volume of Truss Leg

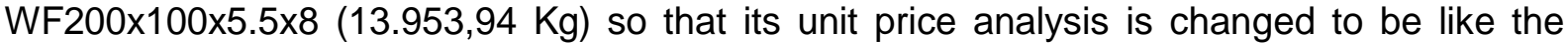
table below and the values in the material column can be used as Cost Value of the work:

Table 10 - Unit Price Analysis of WF200x100x5.5x8 (13.953,94 Kg)

\begin{tabular}{|c|c|c|c|c|}
\hline Coef & Unit & Material & Unit Price & Total \\
\hline 16047,03 & Kg & WF Steel & IDR 36.000,00 & IDR 577.693.116,00 \\
\hline \multicolumn{3}{|c|}{ Total (1) } & IDR 577.693.116,00 \\
\hline 837,236 & Person & Workers & IDR 88.000,00 & IDR 73.676.803,20 \\
\hline 837,236 & Person & Welder & IDR 121.000,00 & IDR 101.305.604,40 \\
\hline 83,72364 & Person & Head of Handyman & IDR 132.000,00 & IDR 11.051.520,48 \\
\hline 41,86182 & Person & Foreman & IDR 154.000,00 & IDR 6.446.720,28 \\
\hline \multicolumn{4}{|c|}{ Total (2) } & IDR 192.480.648,36 \\
\hline \multicolumn{4}{|c|}{ Total (1) +(2) IDR 770.173.764,36 } \\
\hline
\end{tabular}

On the other hand, to obtain Worth Value from the work, it only should be assumed by using, material unit price analysis which can substitute it which is steel WF $175 \times 90 \times 5 \times 8$ with the same calculation as in the table below:

Volume $=$ Length $\times$ Steel WF $175 \times 90 \times 5 \times 8=11.846,45 \mathrm{Kg}$

Tabel 11 - Unit Price Analysis of WF 175x90x5x8 (per $1 \mathrm{~kg}$ )

\begin{tabular}{|c|c|c|c|c|}
\hline Coef & Unit & Material & Unit Price & Total \\
\hline 13623,42 & $\mathrm{Kg}$ & WF Steel & IDR $36.000,00$ & IDR $490.443 .030,00$ \\
\hline \multicolumn{4}{|c|}{ Total (1) } & IDR $490.443 .030,00$ \\
\hline 710,787 & Person & Workers & IDR $88.000,00$ & IDR $62.549 .256,00$ \\
\hline 710,787 & Person & Welder & IDR $121.000,00$ & IDR 86.005.227,00 \\
\hline 71,0787 & Person & Head of Handyman & IDR $132.000,00$ & IDR 9.382.388,40 \\
\hline 35,53935 & Person & Foreman & IDR $154.000,00$ & IDR 5.473.059,90 \\
\hline \multirow{2}{*}{\multicolumn{4}{|c|}{$\begin{array}{c}\text { Total (2) } \\
\text { Total (1) + (2) }\end{array}$}} & IDR 163.409.931,30 \\
\hline & & & & IDR $653.852 .961,30$ \\
\hline
\end{tabular}

From the table above, comparion of Cost Value and Worth Value are obtained for concrete work which can be seen in tabe 12 .

Table 12 - Function Analysis of WF Steel Work (Basic Function: Hold Loading)

\begin{tabular}{|c|c|c|c|c|c|c|}
\hline No & Component & Verb & Noun & $(\mathrm{P} / \mathrm{S})$ & Cost & Worth \\
\hline$a$ & $b$ & $c$ & $D$ & $e$ & $f$ & $G$ \\
\hline 1 & WF Steel & Holding & Load & $\mathrm{P}$ & IDR 577.693.116,00 & IDR 490.443.030,00 \\
\hline \multicolumn{5}{|c|}{$\mathrm{n} / \mathrm{n}$} & IDR 577.693.116,00 & IDR 490.443.030,00 \\
\cline { 4 - 6 }
\end{tabular}

Detail: $P=$ Primary, $S=$ Secondary .

Comparison of Cost / Worth ratio $=1,178>1$, then there is a cost that is not needed.

Speculation / Creative Phase. After determining the working items that will have value engineering (roofing and footing working item), the next phase is speculative / creative phase. In this phase, structure re-planning is done especially for footing and roofing of steel WF. For structure planning, engineering mechanical calculation is done by the help of civil 
engineering working tool (StaadPro); afrer doing it, footing planning is done. For steel WF roofing planning, civil engineering helping tool (StaadPro) is done. For loading and structure planning calculation itself, it can be seen on appendices; the loading in this planning ignores earthquake loading because the development site in Kalimantan Island does not have earthquake, so that this value engineering is able to obtain an efficient and a safe planning. Below is the footing and the roofing structure planning.

Table 13 - Footing Design Alternative

\begin{tabular}{|c|c|c|c|}
\hline \multirow{2}{*}{ No } & \multirow{2}{*}{ Working Items } & \multicolumn{2}{|c|}{ Dimension } \\
\cline { 3 - 4 } & & $25 \times 25$ & VE \\
\hline 1 & Pile Procurement & $25 \times 25$ & Removed \\
\hline 2 & Piling & 0,05 & 0,05 \\
\hline 3 & Rebated Concrete & $65 \times 65 \times 30$ & $80 \times 80 \times 30$ \\
\hline 4 & P1 Pile Cap & $155 \times 65 \times 30$ & $155 \times 80 \times 30$ \\
\hline 5 & P2 Pile Cap & \multicolumn{2}{c}{} \\
\hline
\end{tabular}

From the table above, it can be knoen that the footing design alternative of value engineering, for pile cap working item (P1 \& P2) and piling for Pile cap (P1 \& P2), it has pile cap dimension change in which the initial dimension of $\mathrm{P} 1$ is $65 \times 65 \times 30$, but after doing value engineering, the dimension value of $\mathrm{P} 1$ becomes $80 \times 80 \times 30$. Then, the initial dimension of P2 Pile cap is $155 \times 65 \times 30$ becomes bigger which is $155 \times 80 \times 30$ after value engineering. Although it obtains a bigger resut from P1 and P2 pile cap dimension, but the work of pile procurement and piling are removed. It is because on the value engineering structure calculation, Pile cap (P1 \& P2) is able to hold construction on it without being supported by pile, but Pile cap dimension (P1 \& P2) is maximized. After getting the footing structure value engineering calculation, then roofing steel WF calculation is done. For steel WF planning calculation itself is done by the help of Civil Engineering working program (StaadPro) in which its result can be seen in the table below.

Table 14 - Roof Design Alternative of WF Steel

\begin{tabular}{|c|c|c|c|}
\hline \multirow{2}{*}{ No } & \multirow{2}{*}{ Working Items } & \multicolumn{2}{|c|}{ Dimension } \\
\cline { 3 - 4 } & WF Column & $200 \times 100 \times 5.5 \times 8$ & VE \\
\hline 1 & WF Truss Leg & $200 \times 100 \times 5.5 \times 8$ & $175 \times 90 \times 5 \times 8$ \\
\hline 2 & WF Hemisphere & $200 \times 100 \times 5.5 \times 8$ & $175 \times 90 \times 5 \times 8$ \\
\hline 3 & &
\end{tabular}

From the table above, it can be seen that for the initial roofing structure dimension of WF Steel is $200 \times 100 \times 5.5 \times 8$, the after value engineering, the stee WF dimension becomes $175 \times 90 \times 5 \times 8$. From the data, it can be concluded that there is a cost or a budget saving for steel WF roofing.

Analysis Phase. In this analysis phase, structure cost budget will have value engineering in which it will be analyzed further. The design cost of footing and roofing is discussed further. In this case, material unit price and workers attempt are determined based on or according to the analysis of material unit price list and workers' minimum wages in Human Settlements Office of Kutai Kartanegara Regency. For more details, it can be seen in the table below.

Table 15 - Analysis of Footing Cost

\begin{tabular}{|c|c|c|c|c|c|c|}
\hline No & Working Items & Dimension After VE & Total & Volume & Unit Price & Total \\
\hline 1 & Pile Procurement & 0 & 0 & 0 & IDR $346.830,00$ & IDR - \\
\hline 2 & Piling & 0 & 0 & 0 & IDR $152.136,00$ & IDR - \\
\hline 3 & P1 Pile cap & $80 \times 80 \times 30$ & 81,00 & 15,552 & IDR $939.899,80$ & IDR 107.929.321,71 \\
\hline 4 & P2 Pile cap & $155 \times 80 \times 30$ & 104,00 & 38,688 & IDR 6.035.677,96 & IDR 233.508.309,03 \\
\hline \multicolumn{7}{|c|}{ Cost Grand Total } \\
\hline
\end{tabular}


From the table shown above, it can be seen the budget needs of footing especially for Pile Cap (P1 \& P2) with Pile cap dimension (P1 \& P2) is maximized and the budgets for pile procurement and piling are removed which finally obtains the budget of IDR 341.437.630,74. After getting cost budget for footing after value engineering, then the similar calculation is done for roofing in which its result can be seen in the table below.

Table 16 - Cost Analysis of Roofing

\begin{tabular}{|c|c|c|c|c|c|c|}
\hline No & Working Items & Dimension After VE & Length & Volume & Unit Price & Total \\
\hline 1 & WF Column & $175 \times 90 \times 5 \times 8$ & 56,00 & 1013,60 & IDR 55.194,00 & IDR 55.944.638,40 \\
\hline 2 & WF Truss Leg & $175 \times 90 \times 5 \times 8$ & 654,50 & 11846,45 & IDR 55.194,00 & IDR 653.852.961,30 \\
\hline 3 & WF Hemisphere & $175 \times 90 \times 5 \times 8$ & 42,00 & 760,20 & IDR 55.194,00 & IDR 41.958.478,80 \\
\hline \multicolumn{6}{|c|}{ TOTAL COST } & IDR 751.756.078,50 \\
\hline
\end{tabular}

From the table above, it can be known that the cost budget for roofing especially for the work of WF Column, WF truss leg, and WF Hemisphere is IDR 751.756.078,50.

Development Phase. In this phase, the alternatives selected from analysis phase, cost calculation, and comparison of alternative design cost and project initial design.

Implementation Phase. The final phase of Value Engineering method is implementation phase which means making a recommendation as listed in the table below.

Table 17 - Comparison of Footing Structure Cost

\begin{tabular}{|c|c|c|c|c|c|c|c|c|c|c|c|}
\hline \multirow{2}{*}{ No } & \multirow{2}{*}{$\begin{array}{l}\text { Working } \\
\text { items }\end{array}$} & \multicolumn{2}{|c|}{ Dimension } & \multicolumn{2}{|c|}{ Volume } & \multicolumn{2}{|c|}{ Unit Price } & \multicolumn{4}{|c|}{ Total } \\
\hline & & \multirow{2}{*}{$\begin{array}{l}\text { Initial } \\
25 \times 25\end{array}$} & \multirow{2}{*}{$\frac{\text { VE }}{-}$} & \multirow{2}{*}{$\begin{array}{c}\text { Initial } \\
2312,00\end{array}$} & \multirow{2}{*}{$\frac{\mathrm{VE}}{0,00}$} & \multirow[b]{2}{*}{ IDR } & \multirow[b]{2}{*}{$346.830,00$} & \multicolumn{2}{|r|}{ Initial } & \multicolumn{2}{|r|}{ VE } \\
\hline 1 & $\begin{array}{c}\text { Pile } \\
\text { Procurement }\end{array}$ & & & & & & & IDR & $801.870 .960,00$ & IDR & - \\
\hline 2 & Piling & $25 \times 25$ & - & 2312,00 & 0,00 & IDR & $152.136,00$ & IDR & $351.738 .432,00$ & IDR & - \\
\hline 3 & $\begin{array}{l}\text { Rebated } \\
\text { Concrete }\end{array}$ & 0,05 & 0,05 & 6,95 & 6,95 & IDR & $1.416 .227,35$ & IDR & $9.842 .957,14$ & IDR & $9.842 .957,14$ \\
\hline 4 & P1 Pile Cap & $65 \times 65 \times 30$ & $80 \times 80 \times 30$ & 10,27 & 15,55 & IDR & $6.939 .899,80$ & IDR & $71.250 .216,29$ & IDR & $107.929 .321,71$ \\
\hline 5 & P2 Pile Cap & $155 \times 65 \times 30$ & $155 \times 80 \times 30$ & 31,43 & 38,69 & IDR & $6.035 .677,96$ & IDR & $189.725 .501,08$ & IDR & $233.508 .309,03$ \\
\hline \multicolumn{8}{|c|}{ Total } & IDR & $1.424 .428 .066,51$ & IDR & $351.280 .587,88$ \\
\hline \multicolumn{8}{|c|}{ Saving } & IDR & & & $1.073 .147 .478,63$ \\
\hline \multicolumn{8}{|c|}{ Percentage (\%) } & \multicolumn{4}{|c|}{75,339} \\
\hline
\end{tabular}

Table 18 - Cost Comparison of Roofing Structure

\begin{tabular}{|c|c|c|c|c|c|c|c|c|}
\hline \multirow{2}{*}{ No } & \multirow{2}{*}{ Working Items } & \multicolumn{2}{|c|}{ Dimension } & \multicolumn{2}{|c|}{ Volume } & \multirow{2}{*}{ Unit Price } & \multicolumn{2}{|c|}{ Total } \\
\hline & & Initial & $\mathrm{VE}$ & Initial & $\mathrm{VE}$ & & Initial & VE \\
\hline 1 & WF Column & $200 \times 100 \times 5.5 \times 8$ & $175 \times 90 \times 5 \times 8$ & 1193,92 & 1013,60 & $\begin{array}{c}\text { IDR } \\
55.194,00\end{array}$ & $\begin{array}{c}\text { IDR } \\
65.897 .220,48\end{array}$ & $\begin{array}{c}\text { IDR } \\
55.944 .638,40\end{array}$ \\
\hline 2 & $\begin{array}{l}\text { WF Truss Leg } \\
200 \times 100 \times 5\end{array}$ & $200 \times 100 \times 5.5 \times 8$ & $175 \times 90 \times 5 \times 8$ & 13953,94 & 11846,45 & $\begin{array}{c}\text { IDR } \\
55.194,00\end{array}$ & $\begin{array}{c}\text { IDR } \\
770.173 .764,36\end{array}$ & $\begin{array}{c}\text { IDR } \\
653.852 .961,30\end{array}$ \\
\hline 3 & $\begin{array}{l}\text { WF Hemisphere } \\
200 \times 100 \times 5.5 \times 8\end{array}$ & $200 \times 100 \times 5.5 \times 8$ & $175 \times 90 \times 5 \times 8$ & 895,44 & 760,20 & $\begin{array}{c}\text { IDR } \\
55.194,00\end{array}$ & $\begin{array}{c}\text { IDR } \\
49.422 .915,36\end{array}$ & $\begin{array}{c}\text { IDR } \\
41.958 .478,80\end{array}$ \\
\hline \multicolumn{7}{|c|}{ Total } & $\begin{array}{c}\text { IDR } \\
885.493 .900,20\end{array}$ & $\begin{array}{c}\text { IDR } \\
751.756 .078,50\end{array}$ \\
\hline \multicolumn{7}{|c|}{ Saving } & \multicolumn{2}{|c|}{ IDR $133.737 .821,70$} \\
\hline \multicolumn{7}{|c|}{ Percentage (\%) } & \multicolumn{2}{|c|}{15,103} \\
\hline
\end{tabular}

Table 18 - Recommendation Form of Footing

Project: Market Development on Yos Sudarso Street

Site: Yos Sudarso Street in Anggana District, Kutai Kartanegara Regency, East Kalimantan.

Working Item: Footing Structure

Initial Planning: P1 Pile Cap Dimension 65×65×30 ; P2 155x65×30, with combination of pile dimension $25 \times 25$

Recommendation: Dimension of P1 Pile Cap $80 \times 80 \times 30$ P2 $155 \times 80 \times 30$, with piling is removed because by maximizing dimension of Pile Cap (P1 \& P2), the supporting force fulfills without the combination of pile.

Reasons:

- There is cost and time saving

- Quality / strength to hold same loading

Initial Cost: IDR 1.424.428.066,51

Recommendation Cost: IDR 351.280.587,88

Saving: IDR 1.073.147.478,63

Saving percentage occurring is $75,339 \%$

Source: Calculation Results. 
Table 19 - Recommendation Form of Roofing

Project: Market Development on Yos Sudarso Street

Site: Yos Sudarso Street in Anggana District, Kutai Kartanegara Regency, East Kalimantan.

Working Item: Roof Structure

Initial Planning: WF Steel 200x100x5.5x8 Recommendation: WF Steel 175x90x5x8

Reasons:

- There is cost and time saving

- Quality / strength to hold same loading

Initial Cost: IDR 885.493.900,20

Recommendation Cost: IDR 751.756.078,50

Saving: Rp 133.737.821,70

Saving percentage occurring is $15,133 \%$

Source: Calculation Result.

From table 17 and 18 above, it is known that the value engineering cost saving for footing is of IDR $1.073 .147 .478,63$ or of $75,339 \%$ from the cost of footing working item before value engineering which is of IDR $1.424 .428 .066,51$. Then, the cost saving for roofing is IDR $133.737 .821,70$ or of $15,103 \%$ from roofing working item before value engineering which is of IDR 885.493.900,20. After knowing the working items that can get value engineering which at the end can save cost for every working item, then the researcher makes a recommendation for all parties who involve in the project of Market Deveopment on Yos Sudarso Street in Anggana District, Kutai Kartanegara Regency, East Kalimantan.

\section{CONCLUSION}

Based on the result of initial calculation and after value engineering, the comparison of initial design cost which is IDR 1.424.428.066,51 and the cost of value engineering analysis result which is IDR $351.280 .587,88$ is obtained. It means that by implementing the value engineering, it can save IDR 1.073.147.478,63 with saving percentage of $75,339 \%$.

Based on the result of initial calculation and after value engineering, the comparison of initial design cost which is IDR $885.493 .900,20$ and the cost of value engineering analysis result which is IDR $751.756 .078,50$ is obtained. It means that by implementing the value engineering, it can save IDR $133.737 .821,70$ with saving percentage of $15,133 \%$.

\section{REFERENCES}

1. Afandi, A. A. (2010). Optimasi Pemanfaatan Jalan Margonda Raya Depok dengan Metode Value Engineering. Fakultas Teknik Universitas Indonesia. Application Of Value Engineering Building Project (A Case Study Of Hotel Grand Banjarmasin).

2. Azis, S. 2016. Application of Value Engineering on the Construction of Tertiary Irrigation Channel, Research Journal of Applied Sciences, 1(1), 1328-1333.

3. Brinkkemper, S. (1996). Method engineering: engineering of information systems development methods and tools. Information and software technology, 38(4), 275-280.

4. Dell'Isola, A. (1997). Value engineering. Practical Applications... for Design, Construction, Maintenance \& Operations. RS Means Company Inc. Kingston MA.

5. Ibusuki, U., \& Kaminski, P. C. (2007). Product development process with focus on value engineering and target-costing: A case study in an automotive company. International Journal of Production Economics, 105(2), 459-474.

6. Kelly, J., \& Male, S. (2003). Value management in design and construction. Routledge.

7. Miles, L. D. (2015). Techniques of value analysis and engineering. Miles Value Foundation.

8. Paraoulaki, P. E. (2000). Value engineering and its application to the construction industry (Doctoral dissertation, Massachusetts Institute of Technology).

9. Younker, D. (2003). Value engineering: analysis and methodology (Vol. 30). CRC Press. 